\title{
The Stillness in Movement: A Buddhist Reading of Ash-Wednesday
}

\author{
Chutian Xiao* \\ Department of English Studies, Durham University \\ *Correspondence: chutian.xiao@durham.ac.uk
}

\begin{abstract}
Commonly seen as a religious poem that reflects T. S. Eliot's conversion to Catholicism, Ash-Wednesday demonstrates intensively the poet's religious experience, especially the union of the spiritual stillness and the movements in time which verges on mysticism. However, such extraordinary experience can be comprehended from the perspective of Buddhism. It corresponds with the Buddhist concept of suchness, which is further connected to religious meditation and the attitude of nonattachment in face of worldly life. It does not violate the speaker's pursuit for a kind of Christian salvation, for it concerns more the process and the way to achieve the destination than the destination itself.
\end{abstract}

Keywords: T. S. Eliot; Ash-Wednesday; movement; Buddhism; timeless; divinity

Peer review: This article has been subject to a double blind peer review process

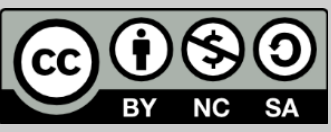

(c) Copyright: The Authors. This article is issued under the terms of the Creative Commons Attribution NonCommercial Share Alike License, which permits use and redistribution of the work provided that the original author and source are credited, the work is not used for commercial purposes and that any derivative works are made available under the same license terms.
Compared with T. S. Eliot's early poetry, there is a new phenomenon in Ash-Wednesday (1930): the introduction of the element of divinity as the imposing other. The intrusion of the omnipotent other is willingly called for and accepted by the speaker, which any earthly activity or feeling must defer to for a new and everlasting meaning. However, the new element does not replace the personal sensibility of the speaker. Rather than questioning all earthly values, the poem focuses on presenting the speaker's state of mind in meditation on the divine figure of the 'Lady', especially in relation to the reality of worldly life. Thus the reader is shown the tension between the spiritual stillness that signifies beatitude and the restless movements of the ego between different distractions. Although the speaker does not eliminate sensuous passions, the meditative mind he acquires in liturgical ritual enables him to appease his ego, which is close to the Buddhist doctrine of non-self. In other words, he achieves spiritual stillness in the world of movement, which corresponds to 'the still point of the turning world' in the first section of Four Quartets, 'Burnt Norton' (Eliot, 2015: 183). This article argues that such stillness in movement is highly similar to the Buddhist 'suchness' of 
life, which denotes the natural state of being. What is more, the explication of the nature of suchness in Buddhism can also smooth the understanding of how, in Ash-Wednesday, the ascetic desert is a potential field of paradise love. From the perspective of Buddhism, the two seemingly distinct spheres ultimately occupy the same plane of existence. It is manifested in the speaker's private sensibility as the reality of the individuals in time, rather than the heavenly realm of timeless divinity. The final peace in God's will demonstrates itself as the tranquillity of the mind that reconciles the restlessly moving consciousness and the calming meditation on the divine. Although AshWednesday is commonly regarded as a dominantly Christian poem, the state of being that the poet painstakingly displays corresponds to the ideal of Buddhist life. Besides, Eliot's formal studies of Buddhism at Harvard made him at least familiar with the Buddhist worldview (Ghosh, 1978: 23). It should be noted that the basic methodology of this article is not to argue that Ash-Wednesday is a poem promoting Buddhism, but to use Buddhism, especially the concept of suchness, to clarify the sensibility that amalgamates the material and the spiritual.

Existing scholarship notes Eliot's efforts to strive for a kind of reconciliation in order to attain spiritual peace, but the nature of that reconciliation is to be further explored. In Poetry and Belief in the Work of T. S. Eliot, Kristian Smidt interprets that Eliot's meant to 'reconcile the reliance on divine grace with the reliance on human effort' (Smidt, 1961: 189). In Ash-Wednesday, the use of prayer can be seen as such an attempt. When prayer becomes an end in itself - that is, it is not for any worldly purpose - it is the integration of inaction and action. It is an essential concept in Indian thought especially pointed out by Eliot in The Dry Salvages, by alluding to Krishna's admonishment in Bhagavad-Gita. The form of the integration in Bhagavad-Gita becomes the devotion and continual contemplation on Krishna, the one true God: 'His heart being unattached to outer object, he finds the joy that is in the Self'

(Nikhilananda, 1944: 174). Its essence, the oneness of the two spheres (time and the timeless) is especially explicated in Buddhism. Cleo McNelly Kearns points out that the Buddhist assertion that phenomenal existence is not different from nirvana is 'to restore to the here and now its full dimension of importance', which is also the main focus of AshWednesday (Kearns, 1987: 109). The here and now is the ground on which the speaker intuitively experiences the timeless with the aid of impersonal prayer. Eliot's emphasis on the here and now reveals his affinity with the Buddhist idea that nirvana does not lie beyond the world in time. However, in order to arrive at that intersection of time and the timeless, a process of spiritual ascent is necessary, so the speaker tells us in Section III of the poem. Such a process towards the union with the 
divine is meticulously elucidated by St John of the Cross, who was regarded by Eliot as one of the greatest 'mystics and saints' (Eliot, 2005: 50). The main argument is that one should empty the mind in order for divine grace to descend. It is similar to Buddhist meditation, which insists on preventing the mind from being occupied by any concept. The major difference is in the goals they pursue. Smidt observes that in Eliot's poetry 'the Oriental view of spiritual discipline has been given great prominence and is juxtaposed with the Christian view of grace' (Smidt, 1961: 189). It seems that in St John of the Cross, Eliot found an example of the integration of the two, which is to use spiritual discipline such as meditation to prepare the mind for divine grace. For Eliot, the best we can do is to be prepared. Further discussion about the difference between the mysticism of St John of the Cross and Buddhist meditation is in the reading of Section III. Moreover, there is also the tendency to view the process of preparation as itself an act inspired by divine grace. In other words, when the speaker abandons the covert desire to acquire divine grace and focuses on prayer, divine grace naturally descends on him, in his act of prayer. While he is in that meditative state of praying, it can be argued that he in his natural state of being, or suchness. Both Hinduism and Christianity put overwhelming emphasis on the absolute reality of the one true God, but Buddhism stresses the efficacy of individual efforts, and plays down the role of a personified God. Eliot does not abandon the idea of an absolute God, but he does not go into theological reasoning about the features of God, either. Rather, his focus is essentially the same with Buddhism, namely the elimination of worldly suffering. The 'eternal end', as Paul Murray puts it in T. S. Eliot and Mysticism, is 'ever still and always present', but for the speaker whose physical existence is bound up to the flow of time, he himself can never become that end, nor is it his goal (Murray, 1991: 48). What is pursued is more a mind of 'shantih', with the kind of 'Peace which passeth understanding', the ideal peace that Eliot envisions at the end of The Waste Land (Eliot, 2015: 77). That is perhaps the kind of common wisdom Eliot sees in Christianity, Hinduism and Buddhism. He argues in On Poetry and Poets that 'wisdom is logos xunos, the same for all men everywhere. If it were not so, what profit could a European gain from the Upanishads, or the Buddhist Nikayas?' (Eliot, 1961: 204) This common wisdom that transcends the doctrinal difference between the three religions is close to what Murray calls 'The real contemplative or mystical gift'. This is 'not so much the ability to transcend the limitations and the horror of time - in order thereby to escape into the realm of the Timeless - but rather the grace and the strength "To apprehend the point of intersection of the Timeless with time"' (Murray, 1991: 106). The following analysis argues that what Eliot apprehends is the stillness in movement, rather than either of them isolated. To read the poem from 
the Buddhism perspective can help us better understand the oneness of the stillness and the movement.

The beginning of the first section implies that the speaker has turned more than once and the turnings bring him pain. 'I no longer strive to strive towards such things' shows that what should be prevented is the desire to strive, rather than the desire for any profitable outcome. The claim strikes at the heart of the issue: the appeasement of the ego, which is the root of subjective striving, is the ultimate solution to stopping the would-be-endless spiritual turning. Rather than personal efforts of asceticism, Buddhism emphasises more on ceasing any purposeful striving towards 'fascinations of objects of attachment' (Warren, 1986: 172). There is a general sense that the speaker resolutely moves towards a specific realm of mind where he can no longer move forward. The speaker cannot drink the illusory water because he does not hope to turn again to the path leading to the despairing nothingness. The Buddhist teaching of non-attachment also builds upon the idea that there is no consistent form in earthly objects, for they are only 'skandha', meaning 'aggregate' or 'a part', which exists only temporarily (Williams, 1956: 1256). A mind unattached with transitory things would not suffer from the pain of loss and disillusion. In the state of non-attachment, the mind rests in the protagonist's state of suchness, or his true self. It seems necessary to clarify the difference between the true self and the ego. As T. R. V. Murti puts it, 'Buddha replaced the soul by the theory of a mindcontinuum, by a series of psychical states rigorously conditioned as to their nature by the casual law governing them' (Murti, 1974: 32). Such a mind-continuum is represented by the ego. On the one hand, Buddhism denies the existence of any eternally unchanged and independent entity and takes the ego as a psychological phenomenon, but on the other hand, 'tathata' or 'suchness' is asserted as 'the intrinsic nature of all things', and evolves into the idea of the true self (ibid: 276). The Sanskrit word 'tathata' implies etymologically 'in that manner, so, thus', and can also be translated as 'thusness' (Williams, 1956: 433). It does not refer to any specific object, entity, or form, but, bypassing them, points to their common state of being existent. It reflects what Nyanaponika Thera calls 'bare attention', when the mind 'attends just to the bare facts of a perception as presented' (Thera, 1962: 30). With bare attention, the consciousness notices things that come to the mind, but is not carried away. Thus the Buddhist true self refers more to a mode of perception than to self-awareness. That is to say, it is fundamentally different from soul or the egotistic self. And what the speaker strives for through religious meditation is the suchness of his whole being. The reason for renouncing the 'the blessèd face' is probably that 'things are as they are' in their perfect suchness, and therefore there is no need to strive for the 
blessed face or anything that plays the role of an object outside the subject (Eliot, 2015: 87). In this sense, what is really renounced is the egotistic efforts to pursue the vision of heavenly bliss.

The intellectual content in the third stanza corresponds to Buddhist suchness in relation to time and space. Seeing that 'what is actual is actual only for one time / And only for one place', the speaker '[rejoices] that things are as they are' (ibid). The observation points to the unique moment of the present in every instant, and the uniqueness of the timespace intersection bestows uniqueness to all things. That is to say, the suchness of things, or their natural state of being, is eternal, not changing with the movements in the flow of time. It is what the speaker can safely rejoice about, unlike the Romantic visions, and the rejoicing is related to not only the problem of stop turning, but also the ambivalent claim of 'having to construct something / Upon which to rejoice' (ibid). It shows that to hold on to the timeless suchness can help the speaker stop turning again, and be 'freed from the eternal cycle' (Smidt, 1961: 145). The way of holding on to it is also the way that enables him to rejoice. The need to rejoice upon some specific object reveals the gap between the personal and the divine as the impersonal, which can be bridged by some medium, or 'skilful means' in Buddhism (Zaleski, 1994: 102). It is analogous to the idea that the suchness of things cannot be grasped without their state of being and mode of movement in specific time and space. In other words, spiritual stillness manifests itself in movement, though not all kinds of movement are pregnant with spiritual stillness. It also reveals the vulnerability of the speaker as a mortal being - he can only rejoice at the suchness in things 'as they are' through some ritualistic act, which, as the rest of the poem shows, is the meditation on the divine Lady.

In order to be able to rejoice, the speaker has to not only 'renounce the blessed face', but 'forget / These matters that with [himself he] too much discuss' (Eliot, 2015: 87). That is to say, he has to return to his own state of suchness, his true self. The true self represents the wholeness of personal sensibility in the consistent response to the changing reality, with the help of which the speaker is able to, as Aelred Graham puts it in Zen Catholicism, 'simultaneously be holy or whole and [natural]' (Graham, 1964: 33). A Buddhist aphorism may better illustrate its significance: before one studies Zen, mountains are mountains and waters are waters; after he gains some relevant knowledge, mountains and waters are not simply mountains and waters; but after he has 'attained the abode of final rest', mountains and waters are really mountains and waters (Abe, 1985: 4). Coincidentally, the three stages of spiritual maturation seem to correspond to the three turnings of stairs in the third section. The first change of mind occurs when the protagonist insightfully sees the 
emptiness of transient beings and sticks to the denial of their relative reality. The second change, which ushers in the ultimate peace, is the consequence of letting go even the idea of emptiness. As Masao Abe points out, '[mountains] and waters disclose themselves in their totality and particularity, and no longer as objects from our subjective vantage point' (ibid). Thus the mountains and waters finally become things 'as they are' in the speaker's eyes, 'actual only for one time / And only for one place' (Eliot, 2015: 87). The true self reins in the ego's tendency of differentiation, and maintains the continual flow of consciousness, preventing it from obsession with any particular movement or image.

If we take 'to care and not to care' as a paradox referring to a particular mode of response to reality, 'to sit still' may be extended to 'sit still and to move at the same time' (ibid: 88). Eliot's refutation that 'why should the mention of "sitting still" suggest a static conception of life' hints at the dynamic stillness embodied in movements (Eliot, 2014: 648). It suggests the general harmony that permeates one's actions in daily life. Whatever the action is, as long as it is in accord to the general harmony, it does not violate the true self. The 'now' is not a present moment that fades into the past, but rather the eternal present. It means that suchness lies in the here and now, regardless of the flow of time. In this sense, every moment contains the life-death paradox, and 'now' is also 'the hour of death' (Eliot, 2015: 88). Therefore, the speaker's praying at the end of the first section is a continuous act, or a state of being.

From the first section to the second, the self-conscious praying is replaced by a pervasive aura of serene objectivity. The musicality of the second section, especially the short lines that create a liturgical aura, makes the content flow more smoothly, and the speaker's over selfconsciousness seems pacified. The presentation of a devotional mind and its natural manifestation of sincerity confirms a certain mode of existence. As John Kwan-Terry puts it, 'what was at first simply one's private experience comes to be confirmed and verified, and established as impersonal and absolute truth' (Kwan-Terry, 1994: 132). The confirmation points to the successful adaptation of a new way of life, realising divine values under worldly conditions. The relationship between the Lady and the Virgin is less important than the Lady's influence on the bones:

Because of the goodness of this Lady

And because of her loveliness, and because

She honours the Virgin in meditation,

We shine with brightness. (Eliot, 2015: 89) 
With the help of the meditation on the Virgin, the speaker elevates his love for the Lady to the level of beatitude, on the base of which he achieves the salutation of her, which in turn sustains the beatitude of pure love. The speaker finds in the lady 'the still point of the turning world', and the holy love of her enables him to see through the transiency of things that are bound to fall into 'oblivion' and 'forgetfulness' (ibid). The Buddhist interpretation of emptiness can help clarify the forgetting of the transient things. It does not mean the psychological loss of memory, but a kind of meditation in which one 'does not seize upon [images] as signs of realities that concern him', and thus 'his mind becomes undistracted' (Conze, 1954: 138). It is more the attitude of non-attachment towards personal memory than the loss of memory. In Buddhism, meditation is used to deepen the concentration of the mind, and help the practitioner achieve non-attachment. Meditative concentration, or 'samadhi', could mean 'skilful one-pointedness of mind', which Paul Griffiths interprets as 'a process by which the awareness is narrowed down from its usual wide spectrum to a specific single point' (Griffiths, 1981: 606). In the poem the centre of concentration is the Lady, and the meditation on her keeps the mind from distractions. In this process, the protagonist achieves inner stillness, while his vitality, or his ability to love, remains unharmed. Furthermore, the mediation directs his mind from objects that please the senses and thus his vitality concentrates more on the pure love of the Lady.

To proffer his deeds to oblivion is also an act of salvation, by ceasing any possessive desire behind all potential deeds. It corresponds to what Kearns discovers, that 'Eliot was particularly attracted to the denial in Buddhism of the substantive reality of [the] ego' (Kearns, 1987: 74). Such oblivion, while purging egotistic purposefulness attaining to the deeds, leaves the ability to love intact. The fruit of the gourd alludes to God's compassionate love for the people of Nineveh: 'Thou hast had pity on the gourd, for the which thou hast not laboured, neither madest it grow; which came up in a night, and perished in a night: and should not I spare Nineveh' (Bible, Jonah 4:10-11 King James Version, cited in notes to Eliot, 2015: 743). It seems self-contradictory to love the fruit of the gourd that grows and perishes so quickly, as the new gourds would experience the same fate. The speaker nonetheless offers to love them, which reveals his wish to acquire selfless and thus universal compassion. In this sense, to proffer his deeds to oblivion means that even though he knows the ephemerality of earthly things, he does not totally cut himself from them. It touches a delicate idea in Buddhism, that non-attachment is different from detachment. Non-attachment is 'seeing into the abode where things are in their suchness', rather than subjectively telling the self apart from other things with a mind of discrimination (Suzuki, 1975: 
123). Non-attachment purges desires to pursue fulfilment and allows universal compassion, while detachment implies self-imposed asceticism and even callousness. In other words, for those who acquire such compassionate love in non-attachment, to live is to love. And the exercise of such love has no purpose but itself. In the faithful contemplation on the Lady, it becomes the perfect means to purge sensuous animal desire without injuring the power of compassion.

The first six pairs of paradoxes in the second stanza all present the double existence of the speaker when he is in meditation on the Lady, though he attributes the double existence to her, the 'Lady of silences' (Eliot, 2015: 89). They are different kinds of silence that people who are totally occupied with desire for earthly gains are unable to know. Similarly, there are also different forms of stillness, when it is incarnated in diverse actions or movements of personal life. To some extent, the mind is capable of sustaining tranquillity in dealing with tasks in secular life. In the meditation on the Lady, the distressed, torn, exhausted and worried people with disturbing memories can find the same kind of calmness and wholeness of the soul, achieve divine forgetfulness, and gain repose. The identification of the single rose and the Garden is the turning point after which opposites disappear, as they converge into the Garden. The garden persists because of the rose, and the existence of the rose can be discerned through the garden. The speaker seems to intuitively realise that for all the time the rose equals the Garden, and in meditation on the rose, the mind is already in the Garden. The language in this stanza creates an aura of liturgical chanting, and peacefulness pervades the lines, as if the speaker's mind enters the realm of the timeless. In other words, the soul is transformed by its willing meditation on the divine. As the pure love of the Lady is perhaps the only kind of love purged of desire for the speaker, all the worldly loves would ultimately wither or develop into the love of the Lady. It is the purpose of itself, as it does not have any demand on the Lady. The act of loving is already the destination. Therefore, it is neither 'love unsatisfied' nor 'love satisfied'; it is love all-time satisfying (ibid: 90).

Section III explains the basic scheme of the whole poem in perhaps the most intellectually clear way compared with the other sections. To ascend the spiritual stairs towards some kind of salvation echoes the spiritual progression described by St John of the Cross in his work such as The Ascent of the Mount Carmel and The Dark Night of the Soul (1991). For St John of the Cross, the major purpose of emptying the mind is for the union with God: 'to empty themselves of all their appetites in order to reach God' (Kavanaugh and Otilio Rodriguez, 1991: 119). However, for Eliot, behind the 'necessity for an absolute, impersonal authority' - to use Barry Spurr's words - there is a deeper need for the 'complete 
submission and abandonment of the self' (Spurr, 2004: 46). After the speaker ascends above the distractions such as 'The broadbacked figure' and the 'music of the flute', the conclusion he arrives at is not a claim of the successful union with God, but the sincere confession that 'Lord, I am not worthy' (Eliot, 2015: 91). It can be argued that in Ash-Wednesday, the speaker's purpose of 'abandonment of all hope as is prescribed by the via negativa' is primarily to '[strip] himself of worldly attachments' which from the Buddhist point of view are the source of suffering (Spurr, 2004: 47-8). In an essay that compares the thought of St John of the Cross and the Buddhist idea of emptiness, Abraham Vélez de Cea points out that in the mystical experience of St John of the Cross, 'what is experienced is the beauty, the life, the grace, and the virtues of all beings in God, rooted in God', while the major purpose of Buddhist meditation is 'the abandonment of views of absolute identity in everything', in order to prevent the mind from being attached with any form of assertion (Vélez de Cea, 2006:141-45). The contemplation on the divine enhances the speaker's awareness of his own situation of existence in worldly life. Moreover, worldly attachments are outshone by pure love towards the Lady in meditation. Thus the speaker's spiritual progress, though it alludes to Christian mystical experience, aims at the intuitive knowledge of 'suffering and its cessation', which is the central teaching of Buddhism (ibid: 145). Earthly life is transformed into a purgatory where the protagonist purifies his mind of distracting attachments by discerning their hollowness. The purgatorial life is the double life of enduring unsettlement and suffering while asserting faith in the calm and eternal bliss. It involves the acceptance of life as it is, and seems to indicate that the purgatorial life is also the life of nirvana. The underlying serenity is similar to the Buddhist non-attachment, which refers to the 'nondualistic, nonconceptual abiding in the present moment' (Zaleski, 1994: 96). At the third stair, the speaker's mind seems to enter a stream of consciousness, as the key concepts and images are piled together:

Distraction, music of the flute, stops and steps of the mind over the third stair,

Fading, fading; strength beyond hope and despair

Climbing the third stair. (Eliot, 2015: 91)

Without the constraint of linguistic conjunctions, his mind intuitively jumps from one notion to another. It is as if in murmuring the speaker sees the nature of the Romantic visions, and as linguistic coherence crumbles, a new order of thought which is more concise leads him to his destination. The repetition of 'Fading, fading' not only indicates the 
fading of the tempting visions, but also the fading of the subjective desire to summon them from memory. To use P.S. Sri's words in T. S. Eliot, Vedanta and Buddhism, that is the moment when the speaker feels that 'the seer and the seen are both ephemeral' (Sri, 1985: 17). Only devotional prayer is real. Now what is supporting him to move forward is not desire, ambition, vanity, or any other kind of worldly motivation, but the 'strength beyond hope and despair', which is generated in the meditative mind that restores the state of suchness (Eliot, 2015: 91).

The focus of Section IV is on Eliot's own version of an earthly paradise. The calmness of the scene seems to have a Buddhist flavour, referring to the speaker's reconciliation with the world. It witnesses the internalisation of the intellectual content of religious belief into personal sensibility. Only after the soul is transformed, can it sincerely utter a voice qualitatively different from the previous one. 'Between' is perhaps the most important word in this section. It witnesses the three major changes of the scenario: from 'who walked between the violet and the violet' to 'Here are the years that walk between', and finally to 'The silent sister veiled in white and blue / between the yews' (ibid: 92). They indicate a never-ending process of spiritual transition, which connects the flowing of time and the eternally fresh present. By focusing on the here and now, the speaker's mind is not carried away by memories or expectancy about the future. The act of talking 'of trivial things' matters more than the trivial things themselves (ibid). Similarly, that the figure 'walked among the others as they walk' is more important than the identities of the others (ibid). In every seemingly trivial act of daily activities lies the secret of nirvana, when the mind rests in 'the sphere of neither cognition nor noncognition', which means for the protagonist to remain unattached while experiencing daily activities (Griffiths, 1981: 610). The poet, by putting the Lady in the peace of the daily life, creates the aura of transcendental calm. It confirms what Smidt says 'the perfect efficaciousness of human effort [...] in all Oriental asceticism' (Smidt, 1961: 188). The Lady acts as others act, but her grace pervades her acts, and because of her the daily becomes timeless. All these happen in the speaker's prayers about and mediation on her.

The lady 'moves in the time between sleep and waking', which is the time of transition and the two worlds of 'sleep and waking' suggest night and day, or even death and life, of the soul. It also suggests the significant moment when the mind is emptied of attachments and not yet filled with new concerns. The Lady is in that state, forever fading and self-renewing. She seems to embody what Kearns calls the 'primal vison or moment of immediate experience' (Kearns, 1987: 234). The experience transcends the difference between the subject and the object, time and the timeless, as well as movement and stillness. Interestingly, the Lady's existence in 
the minds she transforms is all-pervasive, all-penetrating, and always tantalising but always out of reach if the intellect tries to analyse it. D. T. Suzuki argues that in suchness, '[the] actor is the acting, and the acting is the actor' (Suzuki, 1957: 40). It is impossible for the actor to stop acting in order to find acting itself.

The beginning of Section $\mathrm{V}$ tries painstakingly to disentangle the relationship between the creator and the created. As the Word is in fact within the world, the light that 'shone in darkness' does not come from outside the world. Therefore, the speaker's spiritual destination is in the world that he previously wanted to escape from. That is to say, spiritual stillness can be found in the world of movement. It does not concern any specific action, but is reflected in the protagonist's manner of nonattachment when facing the changing world. Unlike the general Christian idea of Heaven independent from earthly life, to seek salvation in life is more in line with Buddhism. Moody deduces that if the worldly noise disappears, 'what will be heard in the absolute silence will be the voice of God' (Moody, 1994: 150). However, if the Word is not without the world, the only way to hear the voice of God is to see through the hollowness of the noise, not to try to eliminate it or wait for its dispersion. Even the elimination or dispersion of the noise is illusory, for the noise is in its nature a kind of impermanent and empty movement. The realisation of the emptiness of the noise naturally suggests the beginning of the divine voice, and the change is more simultaneous than successive. The voice of God cannot be directly heard as something that comes from outside the self, as it is immanent in the world. Thus the only way to hear it is to realise its rhythm in actual life, which suggests that the hearer of the voice of God is the voice itself.

In the final section, the details of the visions of the sea awaken the senses and despite the awareness that they may cause attachment the speaker cannot help but loving them: 'though I do not wish to wish these things' (Eliot, 2015: 96). The life-giving sensuous beauty opens up another possibility: perhaps the key to spiritual salvation does not concern the black-and-white choice between hedonism and asceticism. The salt savour itself is neither good nor evil. By focusing on praying, instead of thinking about 'the profit and the loss', the speaker resumes the mind of non-attachment: 'Teach us to care and not to care / Teach us to sit still / Even among these rocks' (ibid: 97). As the speaker lives in the realm of time with the uncontrollable surges of sensuous passion, what he can do is to renew his faith again and again in prayers. Although the flow of time is out of the speaker's control, time can be redeemed through what John Kwan-Terry calls the 'renewed contact with the eternal' (Kwan-Terry, 1994: 139). It echoes the Buddhist spirit of reconciling the material and the spiritual by focusing on the domain of 
daily life, with unsettling sensations and desires experienced but not adhered to. Nirvana can be accessed in the here and now. As P. S. Sri observes, 'we are caught up in our regrets about the past or in our worries about the future that we are never quite conscious of the innocence and promise of the present' (Sri, 1985: 100). The tranquillity of the new life still accords with the Buddhist suchness. By crying onto the divine, the speaker realises the life of non-attachment on the sphere of worldly existence. The stillness from God is realised in the movement of time-bound life. It seems that in the end Eliot prefers 'the path of the devotee over the path of the sage' (Kearns, 1987: 249). But are not the sages devotional as well? When the devotees are performing acts of devotion, is not their state of devotion a state of life of which the sages approve? To go on trying is to maintain the suchness of the devotional soul. In the act of trying, the devotee and the sage are one.

\section{References}

Abe, Masao (1985), Zen and Western Thought, Honolulu: University of Hawaii Press

Alighieri, Dante (2000), Inferno, trans., Robert Hollander and Jean Hollander, New York: Anchor Book

Conze, Edward (ed.) (1954), Buddhist Texts: Through the Ages, Oxford: Bruno Cassirer

Eliot, T. S. (1961), On Poetry and Poets, New York: Noonday Press

Eliot, T. S. (1976), Selected Essays, London: Faber and Faber

Eliot, T. S. (2014), The Letters of T. S. Eliot Volume 5, in Eliot, Valerie, and John Haffenden (ed.), London: Faber and Faber

Eliot, T. S. (2015), 'Ash-Wednesday', in Ricks, Christopher, and Jim McCue (ed.), The Poems of T. S. Eliot, Volume 1, London: Faber and Faber, pp. 87-97

Eliot, T. S. (2015), 'Baudelaire', in Harding, Jason, and Ronald Schuchard (ed.), The Complete Prose of T. S. Eliot: The Critical Edition, Volume 4, http://muse.jhu.edu/chapter/1690379, accessed 29 May 2017, pp. 155-

64 
Eliot, T. S. (2015), The Poems of T. S. Eliot, Volume 1, Christopher Ricks and Jim McCue (ed.), London: Faber and Faber

Eliot, T. S. (2015), 'Thinking in Verse', in Harding, Jason, and Ronald Schuchard (ed.), The Complete Prose of T. S. Eliot: The Critical Edition, Volume 4, http://muse.jhu.edu/chapter/1690364, accessed 29 May 2017, pp. $44-52$

Ghosh, Damayanti (1978), Indian Thought in T. S. Eliot, Calcutta: Sanskrit Pustak Bhanar

Graham, Aelred (1964), Zen Catholicism, London: Collins

Griffiths, Paul (1981), 'Concentration or Insight: The Problematic of Theravāda Buddhist Meditation-Theory', Journal of the American Academy of Religion, 49 (4), 605-24

Kearns, Cleo McNelly (1987), T. S. Eliot and Indic Traditions, Cambridge University Press

Kwan-Terry, John (1994), 'Ash-Wednesday: a poetry of verification', in Moody, A. D. (ed.), The Cambridge Companion to T. S. Eliot, Cambridge: Cambridge University Press, pp. 132-41

Moody, A. D. (1980), Thomas Stearns Eliot: Poet, Cambridge: Cambridge University Press

Murray, Paul (1991), T. S. Eliot and Mysticism, London: The MacMillan Press

Murti, T. R. V. (1960), The Central Philosophy of Buddhism, London, Allen \& Unwin

Smidt, Kristian (1961), Poetry and Belief in the Work of T. S. Eliot, London: Routledge and Kegan Paul

Spurr, Barry, "'Oh dark dark dark: They all go into the dark," The Via Negativa in the Poetry and Thought of T.S. Eliot' in Hartney, Christopher, and Andrew McGarrity (ed.), The Dark Side: Proceedings of the 2002 Australian and International Religion, Literature and the Arts Conference, Sydney: RLA Press, 2004, https://openjournals.library.sydney.edu.au/index.php/SSR/article/viewFil e/202/181, accessed 26 August 2017, pp. 43-53

St John of the Cross (1991), The Collected Works of St. John of the Cross, trans. Kieran Kavanaugh and Otilio Rodriguez, Washington, D.C.: Institute of Carmelite Studies

Sri, P. S. (1985), T. S. Eliot, Vedanta and Buddhism, Vancouver: University of British Columbia Press 
Suzuki, D. T. (1957), Mysticism: Christian and Buddhist, London: George Allen \& Unwin

Suzuki, D. T. (1975), Studies in the Lankavatara Sutra, London and Boston: Routledge \& Kegan Paul

Swami Nikhilananda (trans.) (1944), Bhagavad-Gita, New York:

Ramakrishna-Vivekananda

Thera, Nyanaponika (1962), The Heart of Buddhist Meditation, London: Rider and Co.

Vélez de Cea, Abraham (2006), 'A New Direction for Comparative Studies of Buddhists and Christians: Evidence from Nagarjuna and John of the Cross', Buddhist-Christian Studies, 26, 139-155

Williams, Monier (ed.) (1956), A Sanskrit-English Dictionary, Oxford: Clarendon

Zaleski, Carol G. (1994), 'Attention as a Key to Buddhist-Christian Dialogue', Buddhist-Christian Studies, 14, 89-110

\section{To cite this article:}

Xiao, C. (2017). The Stillness in Movement: A Buddhist Reading of AshWednesday. Exchanges: the Warwick Research Journal, 5(1), 27-40. Retrieved from:

http://exchanges.warwick.ac.uk/index.php/exchanges/article/view/216 